\section{Attitude towards wearing face mask increases vulnerability of men over women and the risk of Covid-19 pandemic spread in Jos-South metropolis, Plateau State, Nigeria}

\section{Bitrus Inuwa1*, Judith D. Bakam¹, Hassan I. Musa², Idris U.} Hambali², Ismaila Shittu¹, Clement A. Meseko', Dorcas A. Gado', Tony M. Joannis ${ }^{1}$
Submitted: 9 September 2021

Approved: 30 October 2021

Published: 31 October 2021

Address for correspondence:

Bitrus Inuwa, Department of Infectious and Transboundary Disease, National Veterinary Research Institute Vom, Plateau State, Nigeria.

ORCID: https://orcid.org/0000-0003-1582-5956

How to cite this article: Inuwa B, Bakam JD, Musa HI, Hambali IU, Shittu I, et al. Attitude towards wearing face mask increases vulnerability of men over women and the risk of Covid-19 pandemic spread in Jos-South metropolis, Plateau State, Nigeria. G Med Sci. 2021; 2(5): 031-039. https://www.doi.org/10.46766/thegms.pubheal.21090901

Copyright: (c) 2021 Bitrus Inuwa, Judith D. Bakam, Hassan I. Musa, Idris U. Hambali, Ismaila Shittu, Clement A. Meseko, Dorcas A. Gado, Tony M. Joannis. This is an Open Access article distributed under the Creative Commons Attribution License, which permits unrestricted use, distribution, and reproduction in any medium, provided the original work is properly cited.

'Department of Infectious and Transboundary Disease, National Veterinary

Research Institute Vom, Plateau State, Nigeria

${ }^{2}$ Department of Veterinary Public Health and Preventive Medicine, Faculty of

Veterinary Medicine, University of Maiduguri, Borno State, Nigeria

\title{
Background
}

Covid-19 pandemic has hit many countries and put the majority of the public health system to test globally. Mandatory use of facemask was among policies set by the government to contain the spread of the novel disease. But citizens' attitudes and compliance with these policies are important in controlling the pandemic. We assessed gender-based compliance to Covid-19 protocol (use of face mask) in Jos South, Plateau State, Nigeria.

\section{Methods}

Perception regarding Covid-19 and the use of face masks were assessed among participants using a questionnaire-based survey. In a cross-sectional study, ninety $(n=90)$ questionnaires were administered to willing participants directly. A Chi-square test was used to determine the descriptive analysis of all responses, P-values $<0.05$ were considered statistically significant.

\section{Result}

Out of 90 participants, $55.6 \%$ (50/90) were male and $44.4 \%(40 / 90)$ were female. Forty-two (84\%) males deny the existence of the pandemic while in females, 14 (35\%) deny that Covid-19 exist. Thirty-seven (74\%) of the male respondents do not comply with to use of the face mask and use a single face mask multiple times without decontamination. In females, 28 (70\%) comply with the use of the face mask. Unlike the men, 20 (50\%) of the females always decontaminate the face mask. The middle-aged adult (26-45 years) uses the face mask more than the young (18-25 years). There was a significant association of gender in relation to the perception of Covid-19 and the use of facemask $(p<0.05)$. 


\section{Conclusion}

Male respondents showed an irresponsible attitude complying to Covid-19 protocol than the females, therefore, enlisting them as a risk factor for the continued spread of the virus. We recommend that public health awareness and campaigns should focus and employ greater influence on men and young adults in their compliance with the preventive protocols.

Keywords: COVID-19, Attitude, Facemask, Men, Vulnerable.

\section{Introduction}

The novel coronavirus infection (Covid-19) was confirmed to be pandemic on the 11th of March 2020 by the World Health Organization (WHO) [1]. The novel virus reported in Wuhan, China [2] with symptoms that include dry cough, fever, headache, dyspnea, and pneumonia [3] has since become a major public health burden globally. A previously unidentified coronavirus, characterized as the Severe Acute Respiratory Syndrome Coronavirus-2 (SARS-CoV-2), belonging to the ßeta-coronaviruses and with a genomic sequence similar to that of the Severe Acute Respiratory Syndrome Coronavirus (SARS-CoV), was established as the causative agent $[2,4]$. The family Coronaviridae consists of two subfamilies: Letovirinae and Orthocoronavirinae, and the Orthocoronavirinae family having fourgenera: Alpha-coronavirus, Beta-coronavirus, Gamma-coronavirus, and the Delta-coronavirus [5]. Numerous Beta-coronaviruses are human pathogens and cause serious respiratory infections, including the SARS-CoV, the Middle Eastern Respiratory Syndrome Coronavirus (MERS-CoV), and presently, severe acute respiratory syndrome coronavirus-2 (SARS-CoV-2). Coronaviruses are single-stranded (ss), positive-sense (+ve), and enveloped RNA viruses with mammalian and avian species as hosts [2]. Presently there is no treatment against this novel disease; prevention may possibly be the best option in fighting the pandemic [6]. Governments' activities in presenting non-pharmaceutical care as well as procedures that reduce contact of individuals in order to forestall the spread may be the most possible solution in reducing the spread of the novel disease [7]. However, individuals' response to these procedures or guidelines, is reflected in their compliance with guidelines, and their perception of reality, which is a key factor in the health systems to contain the pandemic [8]. Consistent handwashing, staying indoors and use of face masks still remain some of the important preventive measures in fighting this novel disease [8].

Findings recommend that the utilization of face mask could forestall the transmission of respiratory diseases as well as coronavirus. Irrespective of the kind, setting, or who wears the face mask, it helps primarily as a dual protective purpose of shielding the individual from getting been infected and shielding others by preventing viral particles from entering the nose and mouth [9]. The influence of face masks on the spread of diseases has been considered for a long time. The usefulness in the clinical setting is beyond argument. There is also considerable proof that they helped in lessening the spread of epidemics of other respiratory infections such as SARS-CoV of 2002 or influenza (Flu) [10]. In Nigeria for example, as a component of an exhaustive response to Covid-19, according to an official government order, anyone who goes out in public must wear a mask $[11,12]$. A similar policy is being employed by almost all state governments across the country. The Nigerian Centre for Disease Control (NCDC) indicated that the main reason for the public wearing of face masks is to prevent individuals who are infected but asymptomatic from spreading the virus [12]. However, regardless of widely publicized information and knowledge, individuals do not make the best use of the available preventive measures. The aim of this study was to assess participant attitudes in Jos-South LGA, Plateau State, to the use of face mask which provides personal protection against the novel virus. It is also seen as the most effective preventive measure which has been widely maintained to decrease the airborne spread of viruses.

\section{Methodology}

\section{Study Area}

The study was carried out in Jos-South local government area (LGA) of Plateau State, situated around $9^{\circ} 46^{\prime} \mathrm{N} 8^{\circ}$ $48^{\prime} \mathrm{E} / 9.767^{\circ} \mathrm{N}, 8.800^{\circ} \mathrm{E}$ coordinate and the area of 5,104 $\mathrm{km} 2$ (Figure 1). It is located in the North-Western part of the State with its headquarters at Bukuru, which is around fifteen kilometers from the state capital, Jos. The area is about 1,250 meters above sea level. Except for Obudu, in Cross-River State, Jos is the coolest part of Nigeria by the feature of the Plateau. The coldest season is between November to February with an average mean day-to-day temperature of $18^{\circ} \mathrm{C}$ [13].

\section{Study Design and Study Setting}

A cross-sectional questionnaire-based survey was undertaken among residents of Jos-South LGA between September to November 2020. Five to ten minutes questions were administered to 90 participants that were willing to answer a few questions on Covid-19 and use of face mask, directly. Participants' response rate was $100 \%$ as the majority were willing to participate in the exercise. Participation in the survey was made voluntary and also anonymous. It was also completely consistent with the Declaration of Helsinki for the conduct of research involving human subjects [14]. Verbal consent of volunteers who could confirm that they were 18 years old 
or older at the time of the study was eligible to participate. The questionnaire which has two sections was administered to participants. Section 1: Sociodemographic characteristics of the participant. These include: Gender (Male and Female), Age in years and are grouped into two categories of young (18-25) and middleaged adult (26-45). Section 2: Perception regarding COVID-19 and use of face mask. Participants were asked questions on their perception of COVID-19 existence (Yes or No), a participant using face mask (Yes or No), types of face mask used (surgical, respirator, and locally produced facemask), duration of face mask used per day (less than 1 hour or more than 1 hour), multiple uses of single facemask (Yes or No) and decontamination of facemask after usage (Yes or No).

\section{Data Analysis}

The Chi-square (X2) test was used to analyze the associations between socio-demographic characteristics (gender) and participant perception of COVID-19 existence and the use of facemask. $P$ values less than 0.05 were considered statistically significant.

\section{Results}

The result of this survey showed that out of the ninety participants $(n=90)$ that volunteer for this study, $50(55.6 \%)$ were male and $40(44.4 \%)$ were female (Table 1). Fifty-six of the respondents (62.2\%) deny the existence of the novel disease whereas $34(37.8 \%)$ affirm that COVID-19 exists. The study reveals $42(84 \%)$ of the male deny the existence of the COVID-19 pandemic whereas $8(16 \%)$ affirm it, $37(74 \%)$ do not comply with to use of the face mask where $13(26 \%)$ adhere to it, the men respondent, $13(26 \%)$ use the face mask in less than one hour per day. Multiple-use of a single face mask without decontamination was also observed in the male $13(26 \%)$ (Table 1$)$. The young aged (18-25 years) showed low compliance to the use of the facemask than middleaged adults (26-45 years). There was a significant statistical association between gender in relation to COVID-19 pandemic's perception and use of facemask $(\mathrm{p}<0.05)$ (Table 1), 22(24.4\%); 12(13.3\%) and 7(7.8\%) of the respondent in this study use the locally produced, surgical, and respirators types of face masks respectively. Thirteen (26\%) of the male respondent use the face mask in less than one hour per day while 10 (25\%) of female uses the face mask more than 1 hour per day.

\section{Discussion}

This study investigates participant beliefs and attitudes to Covid-19 existence and the use of the face mask. In this study, fifty-six of the respondents (62.2\%) deny the existence of the novel disease where only $34(37.8 \%)$ affirm that it exists. This confirms the earlier report by Ilesanmi [15], who reported that the majority of the populace perceived that Covid-19 is not existing, but a means for politicians to enrich themselves while showcasing their lack of awareness about the pandemic. Since the Covid-19 outbreak in Nigeria, denial, ignorance about the pandemic outbreak as well as the lack of confidence in the government of the country have been identified [16]. Superstitious practices have been around for quite a long time which basically has formed the opinion of some Nigerians concerning the basis and cause of the pandemic [17]. Twenty-six (65\%) of the females respondent accepted the existence of the pandemic while $42(84 \%)$ of the males deny it. This finding is in agreement with previous reports by de la Vega et al.,[18] who reported Covid-19 is less of a concern for men than for women. And this may affect to some extent why fatalities are less in women than in men and who appeared to be more affected by the pandemic than women [19]. These disparities in attitude show that women tend to take the threat more seriously or to be more concerned about it, as well as to be more observant to preventive methods, than men which could be associated with the less prevalence of Covid-19 death in women compared to men [20]. Men equally engage in risky behaviors. There was a significant statistical association $(\mathrm{p}<0.05)$ between gender and Covid-19 perception. Wearing a face mask and other face-covering is best and effective preventive behaviors, which has generally supported to decrease the airborne spread of diseases [21]; however, people are resilient to wearing the face mask in spite of the usefulness of the practice, which poses extreme risks in the context of the pandemic; and these risks are exponentially keen as more people decline to wear the face masks this because each unmasked and infected person multiplicatively rises the possibility of infecting others [22]. Twenty-eight (70\%) of the female respondent in this survey use the facemask more than the male $13(26 \%)$. Thirty-seven ( $74 \%)$ of the male was not using the facemask. This is consistent with findings of [20] who also reported that during epidemics and pandemics like the Covid-19, women were more likely than men to indulge in non-pharmaceutical preventive activities (e.g., mask-wearing) than men; men are considered to engage in other unhealthy, irresponsible lifestyle habits such as drinking, smoking, and drug use at a higher percentage than women [23]. Despite men suffering more from Covid-19, the use of face masks is regarded as disgraceful and some men see it as a sign of weakness [24]. Our findings indicated that middle-aged adult (26-45 years) of both sexes, uses the facemask than the young (18-25 years). This confirms previous studies [18] because the middle-aged adult and the elderly are at higher risk for more severe cases of Covid-19, it is reasonable to assume that this group would wear face masks more frequently than the young [25]. However, the low numbers of young people who wear face masks, combined with their ability to be asymptomatic, create problems for case containment [26]. Mask wearing is necessary across all age groups because of the significant and underreported benefits of source control provided by 
the face masks. Because of the potential for asymptomatic viral infection and spread, lower-risk individuals can put older adults and those with pre-existing illnesses of any age at risk of severe infection by not wearing a mask [20]. As a result, policymakers and the media must inform and alert this age group about the risks of their increasingly relaxed attitudes toward others [18]; policymakers should exert more pressure on men and young individuals to comply with preventive measures. Many that are at high risks, such as middle-aged adults, the elderly, and those with poor health conditions, should make an extra effort to avoid contact with younger people and men, whether they are friends or relatives [20]. Twenty-two (24.4\%); $12(13.3 \%)$ and $7(7.8 \%)$ of the respondents in this study use the locally produced, surgical, and respirators types of face masks respectively. Other surveys that compared the use of face masks to the non-use of the masks, regardless of the form, found that a significantly higher level of infection amongst the participants who did not use the mask. In a survey carried out by Wang et al., [27], infection with SARS-CoV-2 was not reported among the group of members who put on the face mask while the other group of ten members in the no face mask group, infection was recorded. In a related study, the risk of contracting COVID-19 was identified to be thirty-six times greater in persons who used no face masks [27]. Our findings also established that all the male respondent in this study use the face mask in less than one hour per day $13(26 \%)$ while $10(25 \%)$ of female uses the face mask more than an hour per day. The face mask was shown to provide a better form of protection when used continuously, rather than intermittently [28]. Using the facemask for a short period in public places and gatherings still sets others at risk; as Covid-19 spread is mostly through respiratory droplets from diseased persons and even persons without clinical signs (asymptomatic) can still transmit the virus [29]. Therefore, men in this survey stand as a possible risk factor for Covid-19 spread as a single cough or sneeze from an unmasking person in a public place can produce droplets and several smaller airborne particles as every breath and word spoken without a mask on (or one covering mouth and nose) raises the risk of aerosolized virus spread [9]. There was a significant association of gender in relation to the duration of face masks use per day. Multiple-use of a single face mask was also observed in the males $13(26 \%)$ then the females $8(25 \%)$. Where $20(50 \%)$ of the female respondents decontaminates the face mask after usage, none of the males ( $0 \%)$ do the same. This male attitude towards multiple usages of the facemask without decontamination may result in poor filtration proficiency of the facemask, therefore, leading to increased risk. Cloth type masks; must be washed, dried, and if possible ironed after every usage to decrease the risk of infection [9]. Using the face masks will therefore not only safeguard the lives of the user but can also guard the economy because individuals can continue with their daily work and businesses, less likely to be infected by the virus, are able to avoid possible imminent lockdowns because of no upsurge of cases, and ensure people stay fit enough to their places of work [9]. This study has established that male respondents' attitudes can be a risk factor to Covid-19 spread. Therefore, we recommend that public health campaigns should focus and employ greater reinforcement on men, younger age, and the general public in their compliance with the Covid-19 preventive procedures and guidelines.

The findings of this study have to be seen in the light of some limitations that could be addressed in future research. First, the total sample size was relatively small considering the population size of the study area. Future research should assess a larger sample size covering all the wards in the study area (Jos-South). Second, the age group range was narrowed excluding old and very old. Lastly, the educational level of the participants was also excluded, but whose inclusion could have influenced the results in this study.

\section{Acknowledgements}

The authors appreciate all the participants who voluntarily participated in this study.

\section{Conflict of Interest}

The authors declare no conflict of interest.

\section{References}

\section{WHO. Novel Coronavirus (2019-NCoV) 2020.}

2. Zhu N, Zhang D, Wang W, Li X, Yang B, Song J, Zhao, X, Huang B, Shi W, Lu R et al. (2020). A Novel Coronavirus from Patients with Pneumonia in China, 2019. N. Engl. J. Med. https://doi. org/10.1056/nejmoa2001017.

3. Huang C, Wang Y, Li X, Ren L, Zhao J, Hu Y, Zhang L, Fan G, Xu J, Gu, X.; et al. (2020) Clinical Features of Patients Infected with 2019 Novel Coronavirus in Wuhan, China. Lancet. https://doi.org/10.1016/ S0140-6736(20)30183-5.

4. Gorbalenya AE, Baker SC, Baric RS, Groot RJ, Drosten C, Gulyaeva AA, Haagmans BL, Lauber C, Leontovich AM, Neuman BW, et al.(2020). The Species Severe Acute Respiratory Syndrome-Related Coronavirus: Classifying 2019-NCoV and Naming It SARS-CoV-2. Nature Microbiology. https://doi.org/10.1038/s41564-020-0695-z.

5. Cui J, Li F, Shi ZL. (2019). Origin and Evolution of 
Pathogenic Coronaviruses. Nature Reviews Microbiology. https://doi.org/10.1038/s41579-018-01189.

6. Heymann DL, Shindo N. (2020). COVID-19: What Is next for Public Health? The Lancet. https://doi. org/10.1016/S0140-6736(20)30374-3.

7. Wu Z, McGoogan JM (2020). Characteristics of and Important Lessons from the Coronavirus Disease 2019 (COVID-19) Outbreak in China: Summary of a Report of 72314 Cases from the Chinese Center for Disease Control and Prevention. JAMA - Journal of the American Medical Association. 2020. https://doi.org/10.1001/jama.2020.2648.

8. Lee VJ, Chiew CJ, Khong WX (2020). Interrupting Transmission of COVID-19: Lessons from Containment Efforts in Singapore. J. Travel Med. https://doi.org/10.1093/jtm/taaa039.

9. Abboah-Offei M, Salifu Y, Adewale B, Bayuo J, Ofosu-Poku R, Opare-Lokko EBA (2021). A Rapid Review of the Use of Face Mask in Preventing the Spread of COVID-19. Int. J. Nurs. Stud. Adv, 3 (October 2020), 100013. https://doi.org/10.1016/j. ijnsa.2020.100013.

10. Perski O, Simons D, West R, Michie S (2020). Face Masks to Prevent Community Transmission of Viral Respiratory Infections: A Rapid Evidence Review Using Bayesian Analysis. Qeios, 2020. https:// doi.org/10.32388/1sc514.

11. The Presidency A. Office of the Secretary to the Government of the Federation Circular Vol 1 No 3. 2006, Vol 1 No 3.

12. NCDC. Advisory on the Use of Masks by MeMbers of the PUblic WithoUt ResPirAtory SyMPtoMs. 2020, 1-4.

13. Marwati S, El-Emary TI, Gupta JK, Yadav RK, Dudhe R, Sharma PK, Sancak K, Ünver Y, Er M, Reddy CS, et al. (2010). Turkish J. Chem., 2010, 53 (2), 391-401.

14. Kong H, West S (2013). WMA DECLARATION OF HELSINKI - ETHICAL PRINCIPLES FOR Scienti c Requirements and Research Protocols. No. October 1975.
15. Ilesanmi O (2020). Perception and Practices during the COVID-19 Pandemic in an Urban Community in Nigeria : A Cross-Sectional Study. 2020, No. September. https://doi.org/10.7717/peerj.10038.

16. Agusi ER, Ijoma SI, Nnochin CS, Njoku-Achu NO, Nwosuh CI, Meseko CA (2020). The Covid-19 Pandemic and Social Distancing in Nigeria: Ignorance or Defiance. Pan Afr. Med. J., 2020, 35 (2), 1-3. https://doi.org/10.11604/pamj.2020.35.2.23649.

17. Chukwuorji JBC, Iorfa SK (2020). Commentary on the Coronavirus Pandemic: Nigeria. Psychol. Trauma Theory, Res. Pract. Policy. https://doi. org/10.1037/tra0000786.

18. de la Vega R, Ruíz-Barquín R, Boros S, Szabo A (2020). Could Attitudes toward COVID-19 in Spain Render Men More Vulnerable than Women? Glob. Public Health. https://doi.org/10.1080/17441 692.2020.1791212.

19. Rasmussen SA, Smulian JC, Lednicky JA, Wen TS, Jamieson DJ (2020). Coronavirus Disease 2019 (COVID-19) and Pregnancy: What Obstetricians Need to Know. American Journal of Obstetrics and Gynecology. https://doi.org/10.1016/j. ajog.2020.02.017.

20. Haischer MH, Beilfuss R, Hart MR, Opielinski L, Wrucke D, Zirgaitis G, Uhrich TD, Hunter SK (2020). Who Is Wearing a Mask? Gender-, Age, and Location-Related Differences during the COVID-19 Pandemic. PLoS One. https://doi. org/10.1371/journal.pone.0240785.

21. Leung NHL, Chu DKW, Shiu EYC, Chan K, Mcdevitt JJ, Hau BJP, Yen H, Li Y, Ip DKM, Peiris JSM, et al. (2020). Respiratory Virus Shedding in Exhaled Breath and Efficacy of Face Masks. Nat. Med., 2020, 26 (May). https://doi.org/10.1038/s41591020-0843-2.

22. Howard MC (2020). Since January 2020 Elsevier Has Created a COVID-19 Resource Centre with Free Information in English and Mandarin on the Novel Coronavirus COVID- 19. The COVID-19 Resource Centre Is Hosted on Elsevier Connect, the Company' s Public News and Information. 2020, No. January. 
23. Hughes TL, Wilsnack SC, Kantor LW (2016). The Influence of Gender and Sexual Orientation on Alcohol Use and Alcohol-Related Problems: Toward a Global Perspective. Alcohol Research: Current Reviews.

24. Capraro V, Barcelo H (2020). The Effect of Messaging and Gender on Intentions to Wear a Face Covering to Slow down COVID-19 Transmission. arXiv https://doi.org/10.31234/osf.io/tg7vz.

25. Docherty AB, Harrison EM, Green CA, Hardwick HE, Pius R, Norman L, Holden KA, Read JM, Dondelinger F, Carson G, et al. (1985). Features of 20 133 UK Patients in Hospital with Covid-19 Using the ISARIC WHO Clinical Characterisation Protocol: Prospective Observational Cohort Study. BMJ, 2020. https://doi.org/10.1136/bmj.m1985.

26. Davies NG, Klepac P, Liu Y, Prem K, Jit M, Pearson CAB, Quilty BJ, Kucharski AJ, Gibbs H, Clifford, S, et al. (2020). Age-Dependent Effects in the Trans- mission and Control of COVID-19 Epidemics. Nat. Med. https://doi.org/10.1038/s41591-020-0962-9.

27. Wang Q, Huang X, Bai Y, Wang X, Wang H, Hu X, Wang F, Wang X, Chen J, Chen Q, et al. (2020). Epidemiological Characteristics of COVID-19 in Medical Staff Members of Neurosurgery Departments in Hubei Province: A Multicentre Descriptive Study. medRxiv. 2020. https://doi.org/10.1101/2020.0 4.20.20064899.

28. MacIntyre CR, Chughtai AA, Rahman B, Peng Y, Zhang Y, Seale H, Wang X, Wang Q (2017). The Efficacy of Medical Masks and Respirators against Respiratory Infection in Healthcare Workers. Influenza Other Respi. Viruses. https://doi.org/10.1111/ irv. 12474 .

29. Guidelines WHO, Guidance IPC, Group D, Gdg IPC (2020). Advice on the Use of Masks in the Context of COVID-19. 2020, No. April, 1-16. 
Table 1: Participant Perception Regarding COVID-19 and Use of Face mask (n=90)

\begin{tabular}{|c|c|c|c|c|}
\hline Variables & $\begin{array}{l}\text { Males } \\
(\mathrm{n}=50)\end{array}$ & $\begin{array}{c}\text { Females } \\
(n=40)\end{array}$ & Total & ${ }^{\star}$ p-value \\
\hline $\begin{array}{l}\text { Participant response/perception to existence of } \\
\text { COVID-19 pandemic } \\
\text { Yes } \\
\text { No }\end{array}$ & $\begin{array}{c}8(16 \%) \\
42(84 \%)\end{array}$ & $\begin{array}{l}26(65 \%) \\
14(35 \%)\end{array}$ & $\begin{array}{l}34(37.8 \%) \\
56(62.2 \%)\end{array}$ & 0.000 \\
\hline $\begin{array}{l}\text { Participant using face mask } \\
\text { Yes } \\
\text { No }\end{array}$ & $\begin{array}{r}13(26 \%) \\
37(74 \%) \\
\end{array}$ & $\begin{array}{l}28(70 \%) \\
12(30 \%)\end{array}$ & $\begin{array}{l}41(45.6 \%) \\
49(54.4 \%)\end{array}$ & 0.000 \\
\hline $\begin{array}{l}\text { Types of face mask used } \\
\text { Surgical mask } \\
\text { Respirators (N95 +FFP) } \\
\text { Locally produced mask }\end{array}$ & $\begin{array}{l}4(8 \%) \\
1(2 \%) \\
8(16 \%)\end{array}$ & $\begin{array}{l}8(20 \%) \\
6(15 \%) \\
14(35 \%)\end{array}$ & $\begin{array}{l}12(13.3 \%) \\
7(7.8 \%) \\
22(24.4 \%)\end{array}$ & \\
\hline $\begin{array}{l}\text { Duration of face mask used per day } \\
\text { Less than } 1 \text { hour } \\
\text { More than } 1 \text { hour }\end{array}$ & $\begin{array}{l}13(26 \%) \\
0(0.0 \%) \\
\end{array}$ & $\begin{array}{l}10(25 \%) \\
18(45 \%) \\
\end{array}$ & $\begin{array}{l}23(25.6 \%) \\
18(20 \%) \\
\end{array}$ & 0.000 \\
\hline $\begin{array}{l}\text { Multiple use of single Face mask } \\
\text { Yes } \\
\text { No }\end{array}$ & $\begin{array}{l}13(26 \%) \\
0(0 \%)\end{array}$ & $\begin{array}{l}8(20 \%) \\
20(50 \%)\end{array}$ & $\begin{array}{l}21(23.3 \%) \\
20(22.2 \%)\end{array}$ & 0.000 \\
\hline $\begin{array}{l}\text { Decontamination of Face mask after usage } \\
\text { Yes } \\
\text { No }\end{array}$ & $\begin{array}{l}0(0 \%) \\
13(26 \%)\end{array}$ & $\begin{array}{l}20(50 \%) \\
8(20 \%)\end{array}$ & $\begin{array}{l}20(22.2 \%) \\
21(23.3 \%)\end{array}$ & 0.000 \\
\hline
\end{tabular}

${ }^{\star}$ Chi-square (X2) test between male and female respondents. 
Table 2: Comparison between gender and age-groups of participant's perception to COVID-19 and use of face mask.

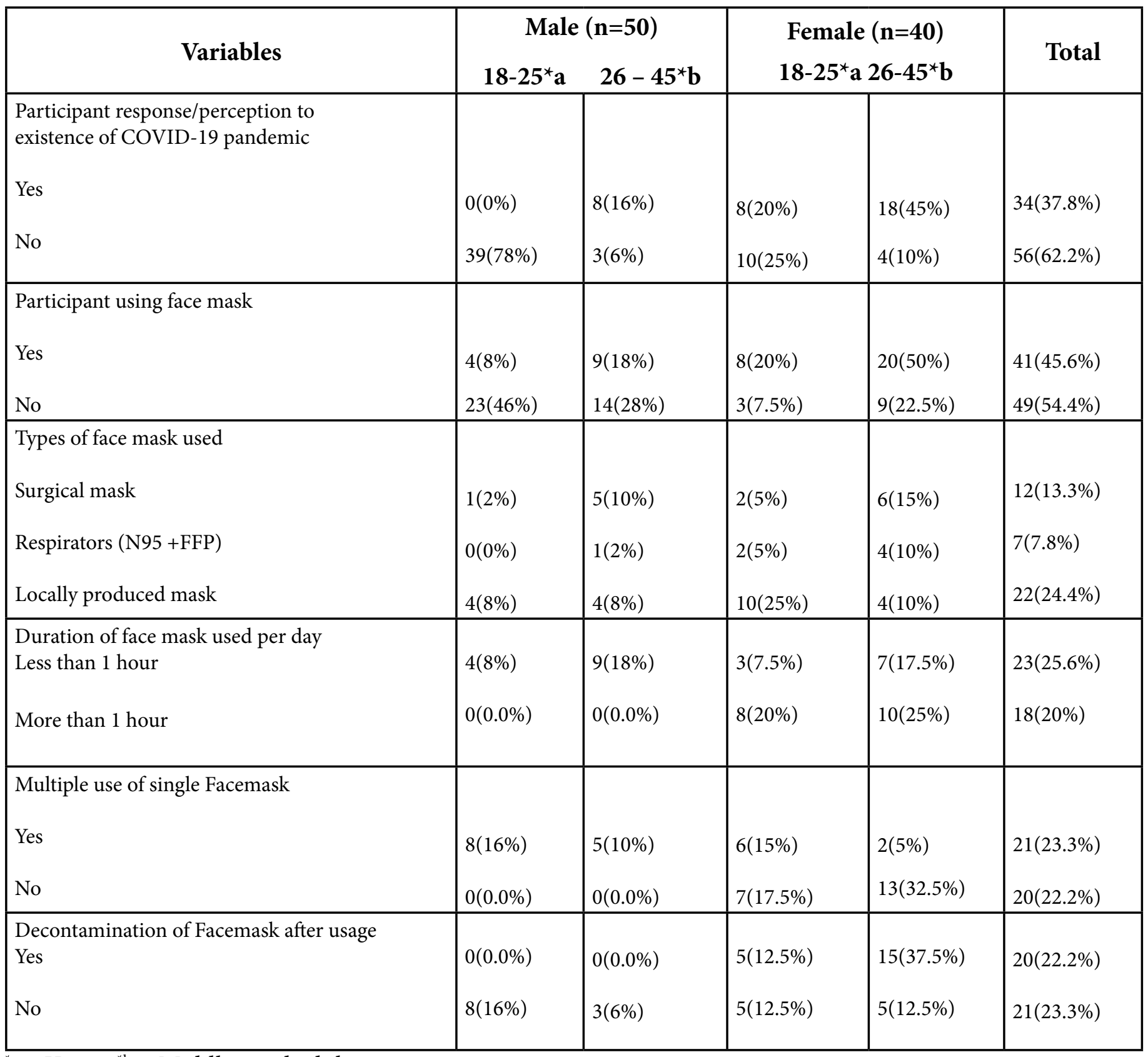

${ }^{{ }^{a}}=$ Young ${ }^{* b}=$ Middle-aged adult 
Figure 1: Map of Nigeria showing Jos-South, Plateau State, study area

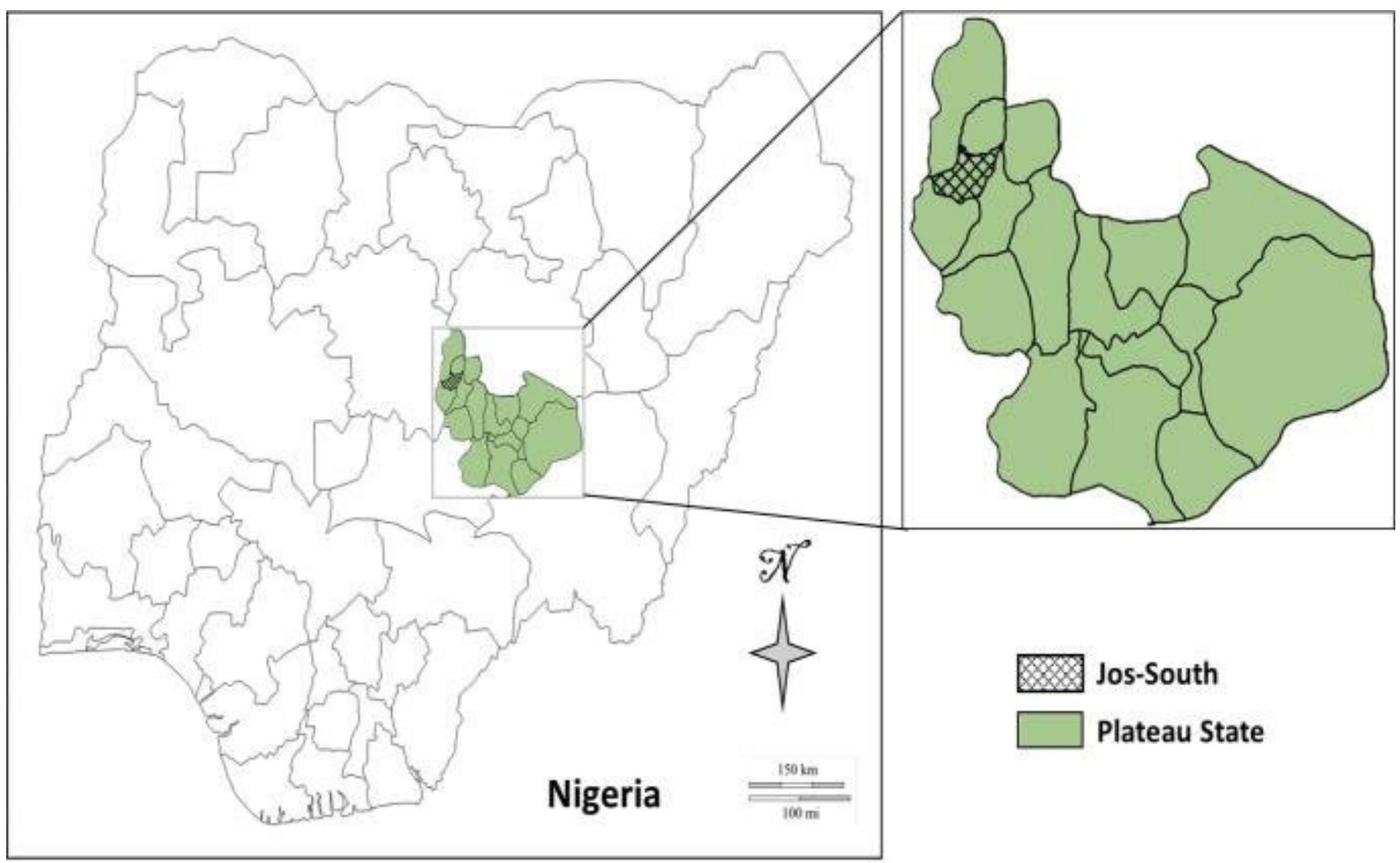

